\title{
The importance of a Biosphere Reserve of Atlantic Forest for the conservation of stream fauna
}

\author{
Yoshida, CE. ${ }^{a}$ and Uieda, $V S .{ }^{b *}$ \\ aAssociação Mata Ciliar, Av. Emílio Antonon, 1000, Chácara Aeroporto, CEP 13212-010 Jundiaí, SP, Brazil

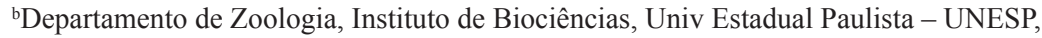 \\ Rubião Júnior, s/n, CP 510, CEP 18618-970, Botucatu, SP, Brazil \\ *e-mail:vsuieda@ibb.unesp.br; vsuieda@gmail.com
}

Received: 12/12/2012 - Accepted: 02/20/2013 - Distributed: 05/31/2014

(With 1 figure)

\begin{abstract}
Preservation of terrestrial fauna and flora has been the main reason for the settlement of most protected areas in the past 30 years, but although those areas may include water bodies, this does not necessarily mean that the biodiversity of freshwater environments are also protected. In the present study, the fauna inventory of eight streams $\left(1^{\text {st }}, 2^{\text {nd }}, 4^{\text {th }}\right.$ and $5^{\text {th }}$ orders) of three microbasins of Japi Mountain, a Biosphere Reserve of Atlantic Forest recognised by UNESCO since 1994, located in São Paulo state, southeast of Brazil, was conducted. The hypothesis of this study is that the conservation of this area is important for the maintenance of the aquatic biodiversity of this biome, and so, this world hotspot deserves priority conservation actions. From 2005 to 2007, benthic macroinvertebrates, fishes and, eventually, anuran amphibians were sampled in these streams. The results showed that Japi Mountain contributes to the conservation of 138 taxonomic units of the aquatic biota and covers a rich and representative biodiversity of freshwater fauna of the world $(0.2 \%)$, Neotropical region $(0.9 \%)$, Brazil $(2.4 \%)$ and São Paulo state $(17.9 \%)$. The studied streams in the Environmental Protection Area help protect endangered taxa like the fishes Neoplecostomus paranensis and Pareiorhina cf rudolphi, and shelter freshwater invertebrates and fishes whose distribution is restricted to the Brazilian territory. Japi Mountain is also an important haven of species that was missing there like the frog species Vitreorana eurygnatha. Thus, this species inventory emphasises the importance of conservation actions of the freshwater environments of this Biosphere Reserve of Atlantic Forest.
\end{abstract}

Keywords: amphibians, freshwater, fish, invertebrates, protected areas.

\section{A importância de uma Reserva da Biosfera da Mata Atlântica para a Conservação da Fauna de Riachos}

\begin{abstract}
Resumo
A conservação da fauna e flora terrestres tem sido a principal razão para o estabelecimento da maioria das áreas protegidas nos últimos 30 anos, porém, apesar de muitas destas áreas apresentarem corpos d'água, isto não significa necessariamente que a biodiversidade dos ambientes dulcícolas também estará protegida. No presente trabalho foi realizado o levantamento da fauna de oito riachos $\left(1^{\mathrm{a}}, 2^{\mathrm{a}}, 4^{\mathrm{a}}\right.$ e $5^{\mathrm{a}}$ ordens) de três microbacias da Serra do Japi, localizada no estado de São Paulo e reconhecida como Reserva da Biosfera da Mata Atlântica pela UNESCO desde 1994. A hipótese do estudo é de que a conservação desta área seja de grande importância para a manutenção de sua biodiversidade aquática, comprovando assim a necessidade de ações prioritárias de conservação deste bioma. No período de 2005 a 2007 foram amostrados nestes riachos os macroinvertebrados bentônicos, peixes e, eventualmente, anfíbios anuros. Os resultados revelaram que a Serra do Japi contribui na conservação de 138 unidades taxonômicas da biota aquática e abriga rica e representativa biodiversidade da fauna de água doce do mundo $(0,2 \%)$, da região neotropical $(0,9 \%)$, do Brasil $(2,4 \%)$ e do estado de São Paulo (17,9\%). Os riachos das áreas de proteção ambiental estudados ajudam na proteção de táxons listados como vulneráveis a extinção no estado, como Neoplecostomus paranensis e Pareiorhina cf rudolphi, e abrigam animais dulcícolas de distribuição restrita ao território brasileiro. A Serra do Japi também constitui um importante reduto de espécies até então desaparecidas, como o anuro Vitreorana eurygnatha. Assim, este levantamento enfatizou a importância de ações de conservação dos ambientes aquáticos desta Reserva da Biosfera da Mata Atlântica.
\end{abstract}

Palavras-chave: anfíbios, água doce, peixes, invertebrados, áreas protegidas. 


\section{Introduction}

Preservation of terrestrial fauna and flora has been the main reason for the settlement of most protected areas in the past 30 years, and because most include water bodies, some of these protected areas also protect the biodiversity of freshwater environments. However, as emphasised by Agostinho et al. (2005), these areas need the inventory studies of species to determine their effective importance to the preservation of the aquatic biota.

The lack of basic knowledge on the biodiversity of freshwater environments in Brazil is an obstacle to preservation studies (Agostinho et al., 2005). According to Rocha (2002), only $30 \%$ of the freshwater invertebrate diversity is presently known and some taxon as Porifera, Cnidaria, Platyhelminthes, Nemertea, Nematoda, Nematomorpha, Bryozoa, Annelida and several insect groups need specialists, collections and/or minimum updated information on identification, distribution and autoecology.

Unlike invertebrates, vertebrates are better known. Regarding the freshwater diversity, fish deserves attention because Brazil is the holder of the largest ictiofauna of the world (Lewinsohn and Prado, 2002; Agostinho et al., 2005). Considering the occurrence and distribution of 2,587 freshwater fish species registered in the country (Buckup et al., 2007), headwater streams have an essential role to preserve this group as $70-80 \%$ of this richness is exclusively and/or preferably found in small water bodies (Buckup, 1999; Castro, 1999; Pompeu et al., 2009; Oyakawa and Menezes, 2010).

The knowledge availability also reflects the number of species considered endangered, and the most studied groups present a greater number of species in the Red Book List of the Endangered Brazilian Fauna (Machado et al., 2008). From 627 species, 194 (31\%) are from freshwater, 134 are fish, 16 are amphibians and 45 are invertebrates.

Besides the need of knowing if the Environmental Protection Areas help the conservation of non-threatened or threatened aquatic taxa, the functionality effectiveness of these areas need to be analysed regarding their contribution as a reserve of local, regional and global biodiversity (Balian et al., 2008). Thus, in the present study, we made the fauna inventory of streams of three micro basins in Japi Mountain, located in a reserve of the Atlantic Forest. We also aimed to contribute to the knowledge of threatened species and areas that may serve as shelter for groups with restrict geographical distribution. The hypothesis of this study is that the conservation of this area is important for the maintenance of the aquatic biodiversity of this biome, and so, this world hotspot deserves priority conservation actions.

\section{Methods}

\section{Study area}

Japi Mountain is located in the countryside of São Paulo state, is part of the Environmental Protection Areas (EPAs) of Jundiaí (47.67\% of the total area), Cabreúva (41.16\%) and Cajamar (0.68\%), and integrates the Piracicaba-Capivari-Jundiaí Water Conservation and Management Unit that gathers important effluents of the Medium Tiete River basin (Figure 1). Japi Mountain has a total extension of 19,170 ha or $350 \mathrm{Km}^{2}$ and it is considered one of the last and biggest remaining continuous area of deciduous seasonal forest area of the state of São Paulo (Morellato, 1992).

In 1994, Japi Mountain was classified by UNESCO as a Reserve of the Atlantic Forest Biosphere and a world hotspot deserving priority actions to preserve its biodiversity. The protection and preservation of Japi Mountain are supported by several legal mechanisms like: the Protection Law for Animals (Decree No 24645/34); Water Code (Decree No 24634/34); Mining Code (Decree No 227/67); Fauna Protection Law (Law No 5197/67); Law for the Creation of Ecological Stations and Environmental Protection Areas (Law No 6938/6902/ 81); Article No 225 of the Federal Constitution 1988 that imposes the public power the preservation and restoration of ecosystems, preservation of diversity and integrity of genetic heritage of the Country; Forestry Code (Federal Law No 4771/65); State Law No 9146/95 about financial compensation mechanisms for municipalities that have protected areas; Resolution No 11 of March 8th 1983 of the Defense Council of the Historical, Archeological, Architectural and Tourism Heritage (Condephaat) on the protection of Japi Mountain area. However, as emphasised by Jesus and Cavalheiro (2004), such legal mechanisms are not enough to guarantee the protection of the area because $90 \%$ of their lands are private properties, the fiscalisation is precarious, and the lack of knowledge about its biodiversity makes its monitoring and management difficult.

The occupation and degradation of Japi Mountain is marked by the construction of Santos-Jundiaí Railroad in 1867 which led to logging of the area so that wood could be used as fuel by locomotives. Later, due to the need of human settlement expansion in the region, there was the substitution of natural areas for cultivation areas (coffee, sugarcane, rice, wheat, beans, potato, Pinus) and cattle farming. Recently, the construction of two important highways (Rodovia Anhangüera and Rodovia Marechal Rondon) has brought part of the development of the city of São Paulo to the cities of Jundiaí, Campinas and Itu, increasing the urbanisation process in natural areas close to these great urban centers (Jesus and Cavalheiro, 2004). Presently, the environmental problems of Japi Mountain are associated with real estate speculation, fires caused by agricultural activity, cattle raising, balloons, vegetation suppression and land movement by private individuals, hunting, mining and vandalism (Yoshida and Gonçalves, 2004).

The conservation state of Japi Mountain streams is related to the environmental zoning that defines the areas of the Biological Reserve and areas of the Preservation Zone (State Decree No 43.284/98 of São Paulo and Municipal Law No 417/04 of Jundiaí). Only three out of eight studied stretches of Ribeirão Ermida microbasin are located inside the Biological Reserve and are more preserved than the 


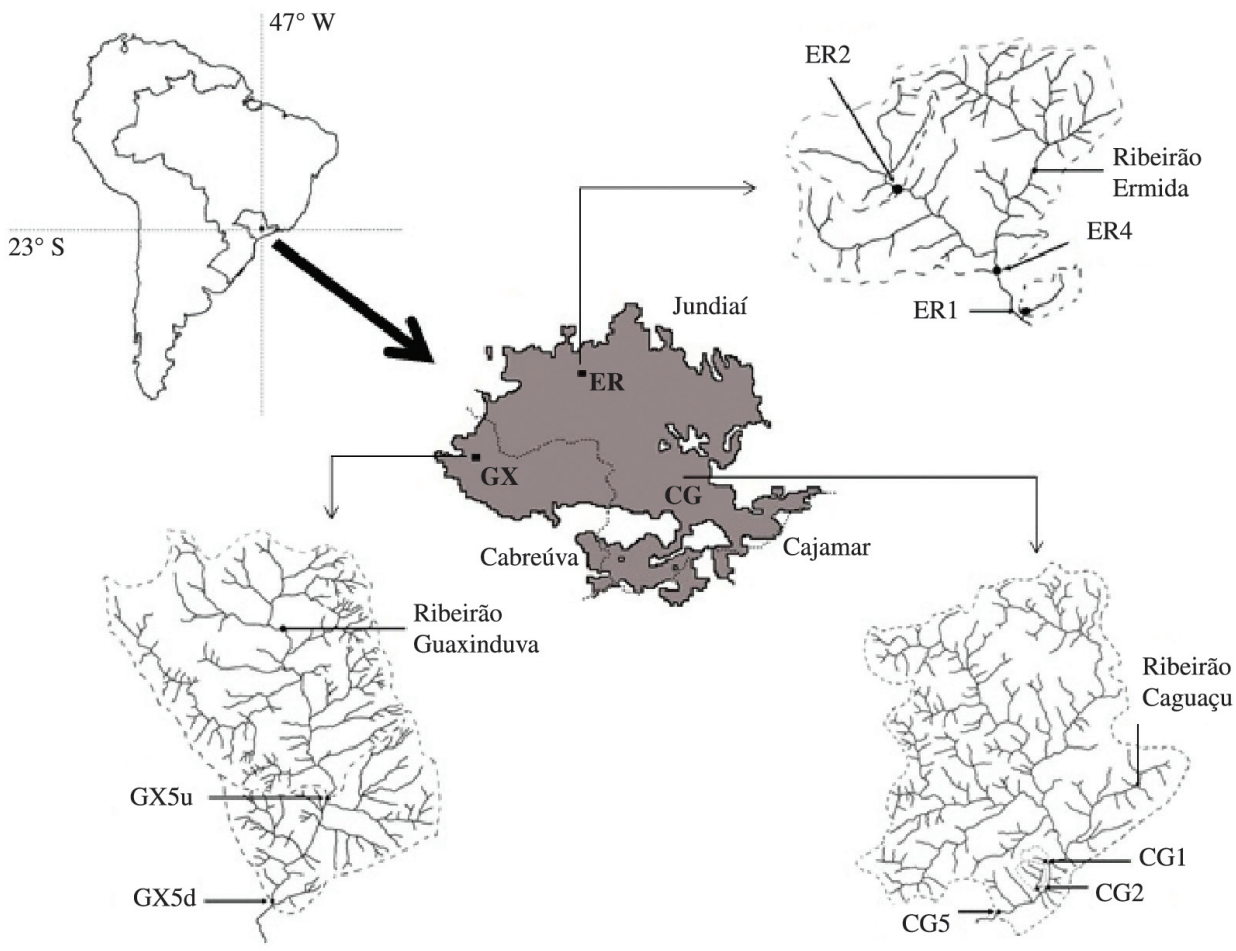

Figure 1. Location of the study area (South America, southeastern Brazil, São Paulo state) with the indication of de limits of Japi Mountain (draw in the center), including the municipalities of Jundiaí, Cabreúva and Cajamar. The hydrographic maps show details of the sampled sites in each of the three studied microbasins (Er- Ermida, GX- Guaxinduva, CG- Caguaçu). The numbers $(1,2,3,4,5)$ refer to the order of the sampled stretches; for Guaxinduva an upstream (GX5u) and a downstream stretch (GX5d) were sampled.

stretches of Guaxinduva and Caguaçu microbasins that are located inside the Preservation Zone, where there is the presence of anthropic activity as agro-forestry-pastoral activities and small residential farms (Table 1, Figure 1).

Because the studied streams present water flow throughout the year, they fit the classification of perennial water courses and are part of a dendritic drainage net (Figure 1), typical of regions with prevalence of rocks that offer resistance to the erosive process (Christofoletti, 1980). Santoro and Machado (1992) reported that in the case of Japi Mountain this resistance is offered by predominant quartzite rocks in the region.

The relief of the terrain where the streams are located presents very weak to medium declivity (from $<6 \%$ to $15 \%$ ) (Florenzano, 2008). Except for three $5^{\text {th }}$ order stretches, the other sampled stretches are small, narrow and shallow, with fast current, high content of dissolved oxygen, low values of temperature and electric conductivity (Table 1). These characteristics for headwater streams have also been emphasised by other authors (Buckup 1999; Valente and Gomes, 2005).

\section{Collection of environmental data}

The morphological characteristics of the microbasins were based on the topographical map of Japi Mountain in a 1:25000 scale, obtained from the Department of
Planning of Jundiaí City. Rainfall and air temperature data of the region of Jundiaí were obtained from the site of the Integrated Centre of Meteorological Information CIIAGRO (www.ciiagro.sp.gov.br, accessed in July, 2008). The measurements of the stream canal and the limnological characteristics were carried out at all collection times of biotic data and at three distinct points of the longitudinal axis of each studied stretch. The streams were characterised according to their length, depth and luminosity (Minipa digital lightmeter, MLM1010 model) and the following physical and chemical water parameters: current (floating method), temperature $\left({ }^{\circ} \mathrm{C}\right.$, measured by an Incoterm thermometer for maximum and minimum temperatures), dissolved oxygen $(\mathrm{mg} / \mathrm{L}$, determined by an Instrutherm oxymeter, model MO880), $\mathrm{pH}$ (measured by a digital pocket $\mathrm{pHmeter}$, model $\mathrm{pH} 1700$ ), electrical conductivity $\left(\mathrm{mS} . \mathrm{cm}^{-1}\right.$, measured with a pocket digital conductometer, model CD840).

\section{Collection of fauna data}

The macrofauna was collected at eight stream stretches of Japi Mountain at two periods: (1) monthly from February 2005 to January 2006, and (2) seasonally, twice in the dry season of 2006 (July and August) and twice in the rainy season of 2007 (January and February). Three microbasins were sampled: Ermida (ER), Guaxinduva 


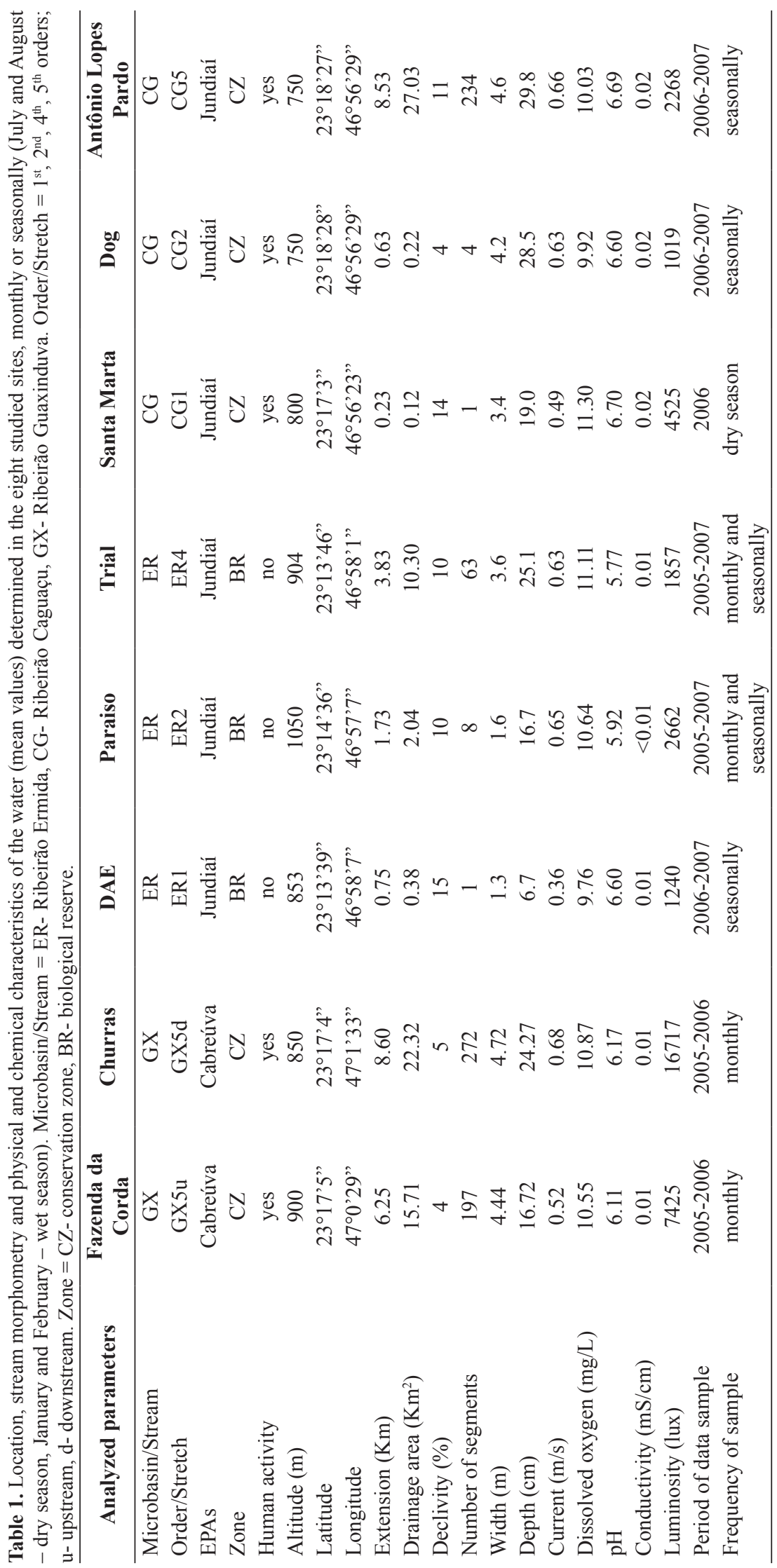


$(\mathrm{GX})$ and Caguaçu $(\mathrm{CG})$, including stretches of $1^{\text {st }}, 2^{\text {nd }}, 4^{\text {th }}$ $5^{\text {th }}$ orders (sensu Strahler classification (Stanford, 1996)), with the orders indicated by numbers near the acronyms' microbasin (Table 1).

Monthly collections were conducted at four stream stretches (GX5u, GX5d, ER2, ER4) (Figure 1). In each stretch, six samples of the macroinvertebrate community were collected in a $30 \mathrm{~m}$ extension with a Surber sampler $(30 \times 30 \mathrm{~cm}$ and $500 \mathrm{~mm}$ mesh). The collected material was stored, transported in ice and later transferred to a refrigerator at $7{ }^{\circ} \mathrm{C}$ until screening (no later than three days after the collection). Macroinvertebrate screening was done visually by spreading the material in a white tray with incident light. The ictiofauna and, eventually, young forms of amphibians were collected along the bank vegetation with a $5 \mathrm{~mm}$ mesh sieve, fixed in formaldehyde $10 \%$ and preserved in alcohol $70 \%$ for posterior identification.

Seasonal collections were carried out in six stream stretches (ER1, ER2, ER4, CG1, CG2, CG5) (Figure 1). In each stretch, five areas of riffles of $5 \mathrm{~m}$ long each were selected in a $100 \mathrm{~m}$ extension for the aquatic fauna collections. In each area, four samples of macroinvertebrates (two from the banks and two from the middle of the stream) were collected with a Surber sampler $(15 \times 15 \mathrm{~cm}$ and $500 \mathrm{~mm}$ mesh), and the visually predominant substrate type in the sampler (sand, litter, gravel, rocks) was recorded. Next, the whole $5 \mathrm{~m}$ area was scanned with a trawl and a dip net (4 mm mesh) to capture fish and, eventually, young and adult anuran amphibians. The macroinvertebrates were fixed and preserved in alcohol $70 \%$ and the fishes were fixed in formaldehyde $10 \%$ and preserved in alcohol $70 \%$ for posterior identification. Macroinvertebrate screening was done with the use of a stereomicroscope.

The collected macroinvertebrates were deposited in the collection of the NGO Associação Mata Ciliar and the Laboratory of Stream Ecology of the Department of Zoology (UNESP - Botucatu). The fish species were deposited in the collection of the Museum of Zoology of USP and the Ichthyology Laboratory of UNESP - São José do Rio Preto.

The identification level of collected organisms was conducted mainly according to the adopted taxonomic levels in programs of macroinvertebrate and fish monitoring, and to the availability of identification keys and of specialists that could verify the identification of collected organisms. The study by Melo (2003) was used to identify Crustacea Decapoda; the studies of Lopretto and Tell (1995), Merritt and Cummins (1996), Nieser and Melo (1997), McCafferty (1998), Fernández and Dominguez (2001), Da-Silva et al. (2002), Costa et al. (2004), Olifiers et al. (2004), Paprocki et al. (2004), Rio Grande do Sul (2006), Passos et al. (2007), Calor (2007) and Manzo and Archangelsky (2008) were used for Insecta identification. The researchers Dr. Gustavo Melo, from the Museum of Zoology of USP, Dr. Sérgio L. S. Bueno, from the Institute of Biosciences of USP, and Dr. Célio Magalhães, from the National Institute of Amazon Research, were consulted for the crustacean identification. The specialists, Dr Melissa O. Segura, Dr. Mateus Pepineli and Dr. Irineu de S. Onofre, from the Department of Limnology of UFSCar, verify the identification of Coleoptera-Elmidae, Diptera-Simuliidae and Odonata, respectively. Dr. Francisco de A. G. de Melo confirmed the identification of Insecta-Orthoptera.

The fish identification was based on the studies by Britski (1972), Menezes et al. (2007), Buckup (1992), Garutti and Britski (2000), Chamon et al. (2005) and confirmed by the specialists Dr. Osvaldo T. Oyakawa, from the Museum of Zoology of USP, and Dr. Francisco Langeani Neto, from the Department of Zoology and Botany (UNESP - São José do Rio Preto).

The amphibians were identified by Daniel Contieri Rolim, from the Herpetology Laboratory of the Department of Zoology UNESP - Botucatu, who utilised the taxonomic key published by Ribeiro et al. (2005) and the descriptions done by Bokermann (1963) and Rada et al. (2007); Dr. Célio Fernando Baptista Haddad, from the Department of Zoology of UNESP-Rio Claro, confirmed their identification.

\section{Results}

The 26,219 specimens, representing 138 taxonomic units and mainly consisting of organisms from the aquatic macrofauna (Tables 2 and 3), were collected in the eight studied streams of Japi Mountain from 2005 to 2007. If each identified taxonomic unit is considered as an equivalent to a species, then Japi Mountain collaborates with almost $20 \%$ of the freshwater biodiversity of São Paulo state (Table 4).

For the macroinvertebrate groups whose identification was more refined (Crustacea and Insecta), the importance of Japi Mountain for the conservation of Brazilian aquatic biodiversity is more evident because the area helps maintain $50 \%$ of the families and $25 \%$ of the freshwater Decapoda and Insecta genera of Brazil (Tables 2 and 5).

Analysing the geographical distribution of nine collected fish families, except for Poeciliidae and Cichlidae, Japi Mountain streams contribute to conserve the ichthyofauna restricted to the American continent, mainly Callichthyidae and Erythrinidae exclusive to South America (Table 3).

Although anurans are not a target in the collection methodology, they were occasionally caught with the fish. Tadpoles of this Centrolenidae species were collected in stream stretches located on Santa Marta Farm (CG1) and at Dog (CG2), outside the area destined to the Biological Reserve of Japi Mountain. From the data published, it is verified that Japi Mountain contributes to the preservation of approximately $14 \%$ (31 out of 225 species) of anuran amphibians recorded in São Paulo state (Table 4).

\section{Discussion}

The average values of physical and chemical measured parameters indicate that the water in the studied streams has little deleterious anthropic influence (based on values of CONAMA Resolution 357/2005) and the studied average variations may be a reflection of the spatial differences related to the conservation state of the stretches as well as natural characteristics of streams like order, morphology and geology of the microbasin. Slightly acid $\mathrm{pH}$, typical 
Table 2. List of the invertebrates sampled in eight streams located in Japi Mountain in the period of 2005-2007. Taxonomic levels and sequence based on Ruppert et al. (2005).

PROTOZOA - "Amoebozoa" - "Lobosea" - testate amebas

ANIMAL

Cnidaria - Hydrozoa - Hydra

Platyhelminthes - "Turbellaria"

Tricladida

Temnocephalida - Temnocephala

Nemertea

Mollusca

Gastropoda

Bivalvia

Annelida

Polychaeta - Histriobdellidae - Stratiodrilus

Oligochaeta

Nematoda

Nematomorpha - Gordioida

Arthropoda

Chelicerata - Arachnida - Acari

Crustacea

Phyllopoda - Cladocera

Malacostraca

Decapoda

Aeglidae - Aegla paulensis Schmitt, 1942

Trichodactylidae - Trichodactylus fluviatilis

Latreille, 1828

Palaemonidae - Macrobrachium iheringi

Ortmann, 1897

Amphipoda - Gammaridea

Isopoda

Maxillopoda

Copepoda

Ostracoda

Tracheata - Hexapoda

Collembola

Isotomidae

Sminthuridae

Onychyuridae

of quartzite soils (Rodriguez and Shepherd, 1992), was probably the factor that influenced the average values of water $\mathrm{pH}$ between 5.8 to 6.7 .

Considering the inventory done by Biota Project FAPESP (Steiner and Amaral, 1999), it is possible to infer that Japi Mountain is an important area to conserve unique species described for the state of São Paulo, like Nemertea Prostoma eilhardi (Montgomeri, 1894) (Forneris, 1999b) and Nematomorpha Paragordius flavescens Linstow, 1906 (Forneris, 1999c), even with the low identification resolution of some less abundant taxa. Besides the validity of the record of Temnocephalida order for the state, not cited by the Biota project (Forneris, 1999a), when contributing to the
Table 2. Continued with Hexapoda. Taxonomic levels based on Merritt and Cummins (1996).

Ephemeroptera

Baetidae

Americabaetis Kluge, 1992

Apobaetis Day, 1955

Baetodes Needham \& Murphy, 1924

Camelobaetidius Demoulin, 1966

Cloeodes Traver, 1938

Paracloeodes Day, 1955

Tupiara Salles, Lugo-Ortiz, Da-Silva \&

Francischetti, 2003

Waltzoyphius McCafferty \& Lugo-Ortiz, 1995

Zelusia Lugo-Ortiz \& McCafferty, 1998

Caenidae - Caenis Stephens, 1835

Euthyplociidae - Campylocia Needham \& Murphy, 1924

Leptohyphidae

Leptohyphes Eaton, 1882

Traveryphes Molineri, 2001

Tricorythodes Ulmer, 1920

Tricorythopsis Traver, 1958

Leptophlebiidae

Askola Peters, 1969

Farrodes Peters, 1971

Hylister Domínguez \& Flowers, 1989

Massartella Lestage, 1930

Miroculis Edmunds, 1963

Thraulodes Ulmer, 1920

Traverella Edmunds, 1948

Odonata

Aeshnidae

Aeshna Fabricius, 1775

Coryphaeschna Williamson, 1903

Limnetron Förster, 1907

Calopterygidae

Coenagrionidae - Argia Rambur, 1842

Corduliidae - Navicordulia Machado \& Costa, 1995

Gomphidae - Progomphus Selys, 1854

Libellulidae - Brechmorhoga Kirby, 1894

Megapodagrionidae

Heteragrion Selys, 1862

Oxystigma Selys, 1862

Orthoptera - Gryllidae - Nemobiinae/Pteronemobiini

preservation of this group, Japi streams help to maintain the ecological ectosymbiosis relation between temnocephalida and crustraceans of the Aegla (Amato et al., 2003) and Trichodactylus genera (Amato et al., 2006). Still using the Biota Project FAPESP inventory results (Steiner and Amaral, 1999), Japi Mountain also collaborates for the conservation of freshwater polychaete of the Stratiodrilus 
Table 2. Continued with Hexapoda. Taxonomic levels based on Merritt and Cummins (1996).

Plecoptera

Gripopterygidae

Gripopteryx Pictet, 1841

Guaranyperla Froelich, 2001

Paragripopteryx Enderlein, 1909

Tupiperla Froehlich, 1969

Perlidae

Anacroneuria Klapálek, 1909

Kempnyia Klapálek, 1916

Hemiptera

Belostomatidae - Belostoma Latreille, 1807

Hebridae - Hebrus Curtis, 1833

Naucoridae - Ctenipocoris Montandon, 1897

Veliidae - Rhagovelia Mayr, 1863

Megaloptera - Corydalidae - Corydalus Latreille, 1802

Trichoptera

Calamoceratidae - Phylloicus Müller, 1880

Ecnomidae - Austrotinodes Schmid, 1955

Glossosomatidae

Itauara Müller, 1888

Mexitrichia Mosely, 1937

Protoptilinae $\mathrm{sp} 1$

Helicopsychidae - Helicopsyche Siebold, 1856

Hydrobiosidae - Atopsyche Banks, 1905

Hydropsychidae

Leptonema Guérin, 1843

Smicridea McLachlan, 1871

Hydroptilidae

Byrsopteryx Flint, 1981

Flintiella Angrisano, 1995

Neotrichia Morton, 1905

Leptoceridae

Grumichella Müller, 1879

Nectopsyche Müller, 1879

Notalina Mosely, 1936

Oecetis McLachlan, 1877

Triplectides Kolenati, 1859

Odontoceridae

Barypenthus Burmeister, 1839

Marilia Müller, 1880

Polycentropodidae - Cyrnellus Banks, 1913

Sericostomatidae - Grumicha grumicha Müller, 1879

Xiphocentronidae - Xiphocentron Brauer, 1870

Lepidoptera - Pyralidae

genus, and it is possible to suggest that $S$. arreliai Amaral \& Morgado, 1997 is present in Japi, considering only the distribution information (proximity to Jaraguá peak) and hosts (Aegla sp.).

Regarding genera and species of crustacean and insects recorded only in Brazil, Japi Mountain streams stand out in the maintenance of the crustaceans Aegla paulensis
Table 2. Continued with Hexapoda. Taxonomic levels based on Merritt and Cummins (1996).

Coleoptera

Curculionidae

Dryopidae

Dytiscidae

Elmidae

Austrolimnius Carter \& Zeck, 1829

Heterelmis Sharp, 1882

Hexacylloepus Hinton, 1940

Huleechius Brown, 1981

Phanocerus Spangler \& Santiago, 1992

Macrelmis Mostchulsky, 1859

Neoelmis Musgrave, 1935

Promoresia Sanderson, 1954

Stegoelmis Hinton, 1939

Xenelmis Hinton, 1936

Larvae C (based on Passos et al. (2007))

Larvae D (based on Passos et al. (2007))

Elminae sp1

Psephenidae

Psephenus Haldeman, 1853

Eubriinae sp 1

Scirtidae

Diptera

Blephariceridae

Ceratopogonidae

Atrichopogon Kieffer, 1906

Bezzia Kieffer, 1899

Chaoboridae

Chironomidae

Dixidae

Empididae

Muscidae

Psychodidae

Simuliidae

Simulium anamariae Vulcano, 1962

Simulium incrustatum Lutz, 1910

Stratiomyidae

Tabanidae

Tipulidae

Hymenoptera

Diapriidae

Scelionidae

(Bond-Buckup et al., 2008) and Macrobrachium iheringi (Coelho and Ramos-Porto, 1984), the Ephemeroptera Tupiara (Salles et al., 2003), the Plecoptera Kempnyia and Guaranyperla (Lecci \& Froelich 2007) and the Trichoptera Mexitrichia (Flint et al., 1999).

Out of 121 fish species of streams recorded in the Atlantic Forest area in São Paulo state (Menezes et al., 2007), 31 
Table 3. Taxonomic list of vertebrates sampled in eight streams located at the Japi Mountain, in the period of 2005-2007. The worldwide area of occurrence of the families is indicated as: SAm- South America, CAm- Central America, NAm- Norte America, NT- Neotropic, AF- Africa, OR- Orient. Taxonomic levels of fish groups based on Reis et al. (2003); occurrence data for fish based on Lucinda (2008) and Menezes et al. (2007) and for amphibians based on Duellman (1999).

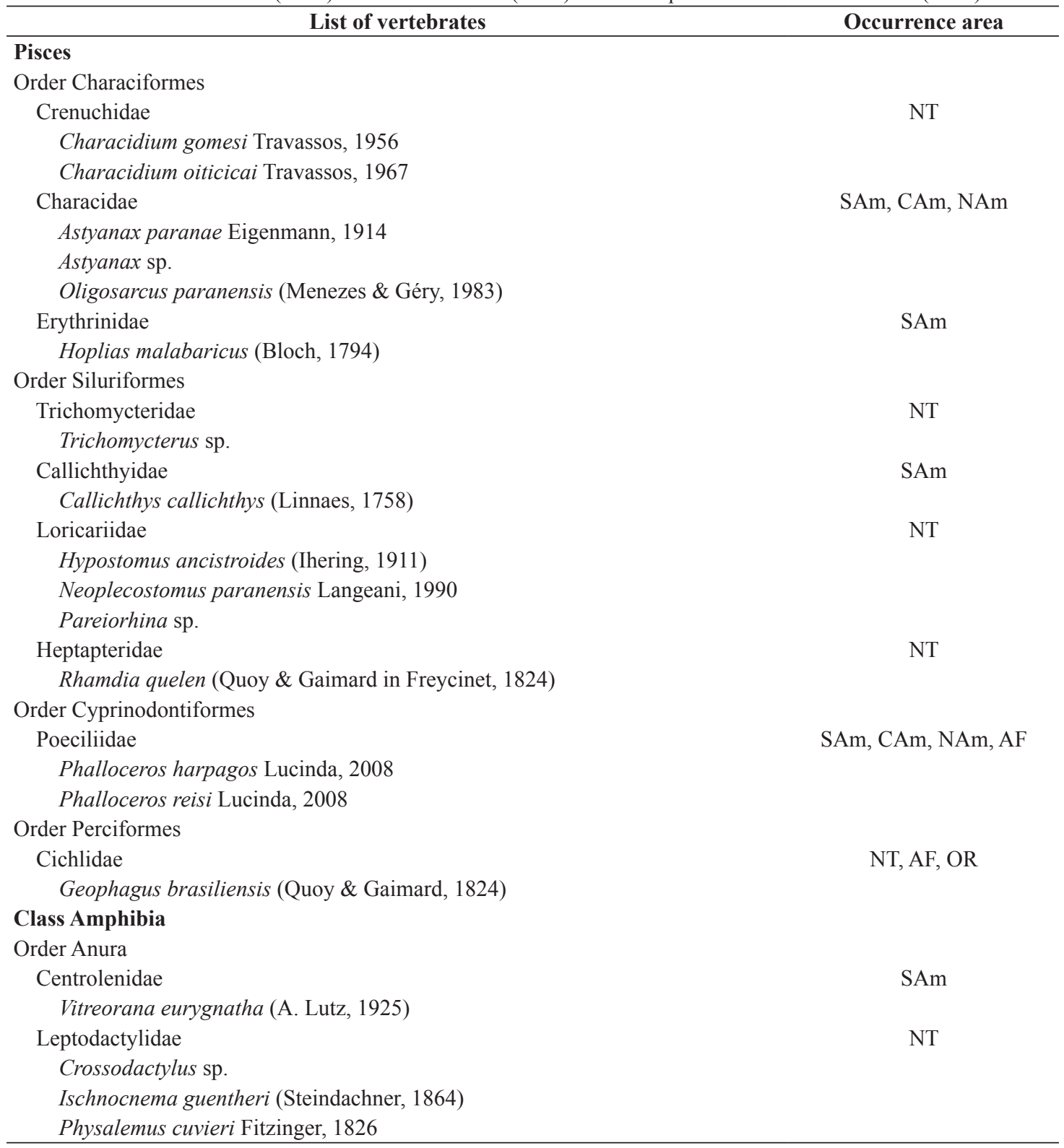

species (25\%) were recorded in Japi Mountain (Rolla et al., 2012). In our study, ichthyofauna sampled in 8 streams represented a high percentage of orders $(67 \%)$, families $(82 \%)$, genera $(50 \%)$ and species $(47 \%)$ also surveyed by Rolla (2008) at fifteen collection stations of Japi Mountain.

Brazilian freshwater fishes are classified in nine orders, six of which occur in the streams of the Atlantic Forest (Oyakawa et al., 2006; Menezes et al., 2007). Characiformes, Siluriformes, Cyprinodontiformes, Synbranchiformes and Perciformes are broadly distributed worldwide and
Gymnotiformes order presents distribution limited to Nearctic and Neotropical regions (Lévêque et al., 2008). With identification refinement, it is noticed that Japi Mountain streams preserve broadly distributed genera and species nationwide (Callichthys callichthys, Trichomycterus, Rhamdia quelen, Astyanax, Hoplias malabaricus), species only distributed in the eastern and southeastern basins of the country (Phalloceros harpagos and Geophagus brasiliensis), and species limited to the basins of Alto Paraná, Tietê, Paraíba do Sul and Paranapanema rivers 
Table 4. Total number (or the lowest estimated value) of freshwater macrofauna species described in the world, in the Neotropical region (NT), in Brazil, in the State of São Paulo (SP) and in Japi Mountain. References: 'Manconi and

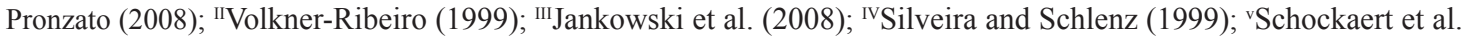
(2008); VIForneris (1999a); ${ }^{\mathrm{VII}}$ Sundberg and Gibson (2008); ${ }^{\mathrm{VII}}$ Forneris (1999b); ${ }^{\mathrm{IX}}$ Abebe et al. (2008); ${ }^{\mathrm{X}}$ Poinar Junior (2008); ${ }^{\mathrm{I}}$ Forneris (1999c); XIIMassard and Geimer (2008); XIIIForneris (1999e); ${ }^{\mathrm{XIV}}$ Bogan (2008); ${ }^{\mathrm{Xv}}$ Avelar (1999); ${ }^{\mathrm{xVI}}$ Strong et al. (2008); ${ }^{\mathrm{XVII}}$ Simone (1999); ${ }^{\mathrm{XVIII}} \mathrm{Glasby}$ and Timm (2008); ${ }^{\mathrm{XIx}}$ Steiner and Amaral (1999); ${ }^{\mathrm{Xx} M a r t i n}$ et al. (2008); ${ }^{x I}$ Righi (1999); XxIIBalian et al. (2008); XxIIIForneris (1999d); XxIv Mugnai et al. (2010); ${ }^{x x v}$ Magalhães (1999);

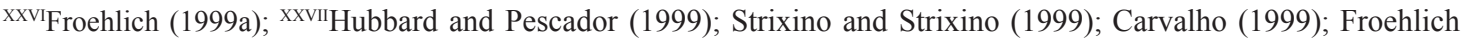
(1999a,b) (*without Coleoptera); xxvIIILévêque et al. (2008); ${ }^{x x I x}$ Buckup (1999) e Buckup et al. (2007) (stream ictiofauna); ${ }^{\mathrm{xxx}}$ Menezes et al. (2007) (ictiofauna of Atlantic forest streams); ${ }^{\mathrm{xx}}$ Rolla et al. (2012); ${ }^{\mathrm{xx} I I}$ Vences and

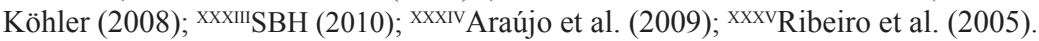

\begin{tabular}{|c|c|c|c|c|c|}
\hline Macrofauna & World & NT & Brazil & SP & Japi \\
\hline Porifera & $219^{I}$ & $65^{\mathrm{I}}$ & $44^{\mathrm{II}}$ & $6^{\mathrm{II}}$ & - \\
\hline Cnidaria & $13^{\mathrm{III}}$ & $?$ & $8^{\mathrm{IV}}$ & $7^{\mathrm{IV}}$ & 1 \\
\hline Platyhelminthes & $1303^{\mathrm{V}}$ & $150^{\mathrm{V}}$ & $84^{\mathrm{VI}}$ & $81^{\mathrm{VI}}$ & 2 \\
\hline Nemertea & $22^{\mathrm{VII}}$ & $4^{\mathrm{VII}}$ & $2^{\mathrm{VIII}}$ & $1^{\mathrm{VIII}}$ & 1 \\
\hline Nematoda & $1801^{\mathrm{IX}}$ & $281^{\mathrm{IX}}$ & $?$ & $?$ & 1 \\
\hline Nematomorpha & $326^{x}$ & $32^{\mathrm{x}}$ & $10^{\mathrm{XI}}$ & $1^{\mathrm{XI}}$ & 1 \\
\hline Bryozoa & $88^{\mathrm{XII}}$ & $30^{\mathrm{XII}}$ & $10^{\mathrm{XIII}}$ & $6^{\mathrm{XIII}}$ & - \\
\hline Bivalvia & $1026^{\mathrm{XIV}}$ & $226^{\mathrm{XIV}}$ & $115^{\mathrm{XV}}$ & $44^{\mathrm{XV}}$ & 1 \\
\hline Gastropoda & $4000^{X V I}$ & $533^{\mathrm{XVI}}$ & $193^{\mathrm{XVII}}$ & $70 \mathrm{XVII}$ & 1 \\
\hline Polychaeta & $168^{\mathrm{XVIII}}$ & $53^{\mathrm{XVIII}}$ & $4^{\mathrm{XIX}}$ & $3^{\mathrm{XIX}}$ & 1 \\
\hline Olighochaeta & $806^{\mathrm{xx}}$ & $178^{\mathrm{xx}}$ & $70^{\mathrm{XXI}}$ & $46^{\mathrm{XXI}}$ & 1 \\
\hline Acari & $6149^{\mathrm{XXII}}$ & $1330^{\mathrm{XXII}}$ & $332^{\mathrm{XXIII}}$ & $20^{\mathrm{XXIII}}$ & 1 \\
\hline Isopoda & $942^{\mathrm{XXII}}$ & $109^{\mathrm{XXII}}$ & $20^{\mathrm{XXIV}}$ & $?$ & 1 \\
\hline Amphipoda & $1866^{\mathrm{XXII}}$ & $127^{\mathrm{XXII}}$ & $?$ & $?$ & 1 \\
\hline Decapoda & $2832^{\text {XXII }}$ & $513^{\mathrm{XXII}}$ & $116^{\mathrm{XXV}}$ & $33^{\mathrm{XXV}}$ & 3 \\
\hline Collembola & $103^{\mathrm{XXII}}$ & $28^{\mathrm{XXII}}$ & $5^{\mathrm{XXVI}}$ & $?$ & 3 \\
\hline Insecta & $75874^{\mathrm{XXII}}$ & $8594^{\mathrm{XXII}}$ & $3464^{\mathrm{XXVII}}$ & $330^{\mathrm{XXVII} *}$ & 97 \\
\hline Pisces & $12740^{\mathrm{XXVIII}}$ & $5546^{\text {XXVIII }}$ & $2060^{\mathrm{XXIX}}$ & $121^{\mathrm{XXX}}$ & $31^{\mathrm{XXXI}}$ \\
\hline Amphibia - Anura & $3978^{\mathrm{XXXII}}$ & $1661^{\mathrm{XXXII}}$ & $849^{\mathrm{XXXIII}}$ & $225^{\mathrm{XXXIV}}$ & $31^{\mathrm{XXXV}}$ \\
\hline TOTAL & 114256 & 19460 & 7342 & 984 & 178 \\
\hline$\%$ of Japi biodiversity & $0.2 \%$ & $0.9 \%$ & $0.4 \%$ & $17.9 \%$ & \\
\hline
\end{tabular}

Table 5. Number of families and genera of the most abundant aquatic macroinvertebrates sampled in Japi Mountain, showing worldwide, national and local data. References: ' $B a l i a n$ et al. (2008); ${ }^{\mathrm{II}} \mathrm{Melo}$ (2003); ${ }^{\mathrm{III}} \mathrm{De}$ Grave et al. (2008); ${ }^{\mathrm{IV}} \mathrm{Yeo}$ et al.

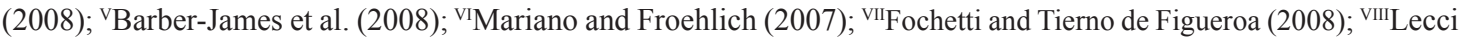
and Froehlich (2007); ${ }^{\mathrm{IX}}$ De Moor and Ivanov (2008); ${ }^{X}$ Paprocki et al. (2004); ${ }^{\mathrm{XI}}$ Wagner et al. (2008); XIIPinho (2008); XIIIJ̈̈ch and Balke (2008); XIVBenetti et al. (2006); ? scanty or inexistent data.

\begin{tabular}{lcccccc}
\hline \multicolumn{1}{c}{ Order } & Families & \multicolumn{3}{c}{ Genera } \\
\hline Decapoda & World & Brazil & Japi & World & Brazil & Japi \\
Ephemeroptera & $46^{\mathrm{I}}$ & $7^{\mathrm{II}}$ & 3 & $629^{\mathrm{III}}$ IV & $26^{\mathrm{II}}$ & 3 \\
Plecoptera & $42^{\mathrm{V}}$ & $10^{\mathrm{VI}}$ & 5 & $400^{\mathrm{V}}$ & $63^{\mathrm{VI}}$ & 22 \\
Trichoptera & $16^{\mathrm{VII}}$ & $2^{\mathrm{VIII}}$ & 2 & $286^{\mathrm{VII}}$ & $8^{\mathrm{VIII}}$ & 6 \\
Diptera & $46^{\mathrm{IX}}$ & $16^{\mathrm{X}}$ & 12 & $610^{\mathrm{IX}}$ & $51^{\mathrm{X}}$ & 23 \\
Coleoptera & $29^{\mathrm{XI}}$ & $23^{\mathrm{XII}}$ & 13 & $\sim 1389^{\mathrm{XI}}$ & $?$ & $?$ \\
\hline
\end{tabular}

(Hypostomus ancistroides, Oligosarcus paranensis, Astyanax paranae, Characidium, Phalloceros reise) (Buckup et al., 2007; Lucinda, 2008). It is noteworthy to point out that Japi Mountain streams also collaborated to conserve endangered species of armored catfish in São Paulo state - Neoplecostomus paranensis and Pareiorhina cf rudolphi.
Although anurans are not a target in the collection methodology, they were occasionally caught with the fish. From four identified species (Table 3), Vitreorana eurygnatha deserves attention because it was believed to be extinct in the region (Ribeiro et al., 2005). Tadpoles of this Centrolenidae species were collected in stream stretches 
located on Santa Marta Farm (CG1) and at Dog (CG2), outside the area destined to the Biological Reserve of Japi Mountain. From the data published by Ribeiro et al. (2005) and Araújo et al. (2009), it is verified that Japi Mountain contributes to the preservation of approximately 14\% (31 out of 225 species) of anuran amphibians recorded in São Paulo state (Table 4).

Concluding remarks - The Japi Mountain (Environmental Protection Areas of Jundiaí and Cabreúva municipalities) is effective in the conservation of aquatic fauna, comprising 138 taxonomic units and showing a rich and representative biodiversity of the freshwater fauna of the world $(0.2 \%)$, Neotropical region (0.9\%), Brazil (2.4\%) and São Paulo state (17.9\%). The streams of these Environmental Protection Areas help the conservation of taxa listed as vulnerable in the state of São Paulo, such as the fish species Neoplecostomus paranensis and Pareiorhina cf rudolphi. These areas also comprise important habitats for freshwater crustaceans, aquatic insects and fish of restrict distribution in South America and in restrict basins of Brazil. The importance of Japi Mountain for the conservation of stream fauna is also emphasised when the occurrence of unknown or believed to be extinct species in the studied streams, like the coleopteran Huleechius and the anuran Vitreorana eurygnatha, are considered. Thus, this species inventory emphasises the importance of conservation actions of the freshwater environments of this Biosphere Reserve of Atlantic Forest.

Acknowledgements - We are grateful to the "Conselho Nacional de Desenvolvimento Científico e Tecnológico" (CNPq - Process Number 142300/2007-1) for the financial support, the anonymous referees for the suggestion to the manuscript and all friends and biology students from Pontifícia Universidade Católica de Campinas (PUC Campinas) who helped us in the field and laboratory procedures.

\section{References}

ABEBE, E., DECRAEMER, W. and LEY, PD., 2008. Global diversity of nematodes (Nematoda) in freshwater. Hydrobiologia, vol. 595, no. 1, p. 67-78. http://dx.doi.org/10.1007/s10750-007-9005-5.

AGOSTINHO, AA., THOMAZ, S. and GOMES, LC., 2005. Conservation of the biodiversity of Brazil's Inland Waters. Conservation Biology, vol. 19, no. 3, p. 646-652. http://dx.doi. org/10.1111/j.1523-1739.2005.00701.x.

AMATO, JFR., AMATO, SB. and DAUDT, LCC., 2003. New species of Temnocephala Blanchard (Platyhelminthes, Temnocephalida) ectosymbiont on Aegla serrana Buckup \& Rossi (Crustacea, Anomura) from southern Brazil. Revista Brasileira de Zoologia, vol. 20, no. 3, p. 493-500. http://dx.doi.org/10.1590/S010181752003000300021 .

AMATO, JFR., AMATO, SB. and SEIXAS, AS., 2006. A new species of Temnocephala Blanchard (Platyhelminthes, Temnocephalida) ectosymbiont on Trichodactylus fluviatilis Latreille (Crustacea, Decapoda, Trichodactylidae) from southern Brazil. Revista Brasileira de Zoologia, vol. 23, no. 3, p. 796-806. http://dx.doi. org/10.1590/S0101-81752006000300026.
ARAÚJO, OGS., TOLEDO, LF., GARCIA, PCA. and HADDAD, CFB., 2009. The amphibians of São Paulo State, Brazil amphibians of São Paulo. Biota Neotropica, vol. 9, no. 4, p. 197-209. http:// dx.doi.org/10.1590/S1676-06032009000400020.

AVELAR, WEP., 1999. Moluscos bivalves. In ISMAEL, D., VALENTI, WC., MATSUMURA-TUNDISI, T. and ROCHA, O. (Ed.). Biodiversidade do Estado de São Paulo, Brasil: invertebrados de água doce. São Paulo: FAPESP. vol. 4. p. 65-68.

BALIAN, EV., SEGERS, H., LÊVÊQUE, C. and MARTENS, K., 2008. The freshwater animal diversity assessment: an overview of the results. Hydrobiologia, vol. 595, no. 1, p. 627-637. http:// dx.doi.org/10.1007/s10750-007-9246-3.

BARBER-JAMES, HM., GATTOLLIAT, J., SARTORI, M. and HUBBARD, MD., 2008. Global diversity of mayflies (Ephemeroptera, Insecta) in freshwater. Hydrobiologia, vol. 595, no. 1, p. 339-350. http://dx.doi.org/10.1007/s10750-007-9028-y.

BENETTI, CJ., FIORENTIN, GL., CUETTO, JAR. and NEISS, UG., 2006. Chaves de identificação para famílias de coleópteros aquáticos ocorrentes no Rio Grande do Sul, Brasil. Neotropical Biology and Conservation, vol. 1, p. 24-28.

BOGAN, AE., 2008. Global diversity of freshwater mussels (Mollusca, Bivalvia) in freshwater. Hydrobiologia, vol. 595, no. 1, p. 139-147. http://dx.doi.org/10.1007/s10750-007-9011-7.

BOKERMANN, WCA., 1963. Girinos de anfíbios brasileiros -2 (Amphibia, Salentia). Revista Brasileira de Biologia $=$ Brazilian Journal of Biology, vol. 23, p. 349-353.

BOND-BUCKUP, G., JARA, CG., PÉREZ-LOSADA, M., BUCKUP, L. and CRANDALL, KA., 2008. Global diversity of crabs (Aeglidae: Anomura: Decapoda) in freshwater. Hydrobiologia, vol. 595, no. 1, p. 267-273. http://dx.doi.org/10.1007/s10750007-9022-4.

Brasil. Constituição, 1988. Constituição da República Federativa do Brasil. Brasília: Senado Federal. Artigo 225. Available from: $<$ http://www.dji.com.br/constituicao_federal/cf225.htm>.

Brasil. Presidência da República, 1934. Decreto n² 24.643, de 10 de julho de 1934. Decreta o código de águas. Diário Oficial da União, Brasília, 20 jul. Available from: < http://www.planalto. gov.br/ccivil_03/decreto/D24643.htm>.

Brasil. Presidência da República, 1965. Lei no 4.771, de 15 de setembro de 1965. Institui o novo Código Florestal. Diário Oficial da União, Brasília, 16 set. Available from: $<$ http://www2. camara.leg.br/legin/fed/lei/1960-1969/lei-4771-15-setembro1965-369026-norma-pl.html>.

Brasil. Presidência da República, 1967. Decreto n ${ }^{\circ} 227$, de 28 de fevereiro de 1967. Dá nova redação ao Decreto-lei no 1.985 , de 29 de janeiro de 1940. (Código de Minas). Diário Oficial da União, Brasília, 28 fev. Available from: $<\mathrm{http}: / / \mathrm{www}$.planalto. gov.br/ccivil_03/decreto-lei/del0227.htm>.

Brasil. Presidência da República, 1967. Lei n ${ }^{\circ}$ 5.197, de 3 de janeiro de 1967. Dispõe sobre a proteção à fauna e dá outras providências. Diário Oficial da União, Brasília, 5 jan. Available from: <http://www.planalto.gov.br/ccivil_03/leis/15197.htm>.

Brasil. Presidência da República, 1981. Lei no 6.938, de 31 de agosto de 1981. Dispõe sobre a Política Nacional do Meio Ambiente, seus fins e mecanismos de formulação e aplicação, e dá outras providências. Diário Oficial da União, Brasília, 2 set. Available from: <http://www.planalto.gov.br/ccivil_03/leis/16938.htm>.

Brasil. Senado Federal, 1934. Decreto $\mathrm{n}^{\circ} 24.645$, de 10 de julho de 1934. Estabelece medidas de proteção aos animais. Coleção de Leis do Brasil, Brasília. Available from: < http://funed.mg.gov. 
br/wp-content/uploads/2010/05/Decreto-lei-24645-34-maustratos-animais.pdf $>$.

BRITSKI, HA., 1972. Peixes de água doce do estado de São Paulo: sistemática. In Comissão Interestadual da Bacia ParanáParaguai. Faculdade de Saúde Pública. Universidade de São Paulo (Ed.). Poluição e piscicultura: notas sobre poluição, ictiologia e piscicultura. São Paulo: Cibpu. p. 79-108

BUCKUP, PA., MENEZES, NA. and GHAZZI, MS., 2007. Catálogo das espécies de peixes de água doce do Brasil. Rio de Janeiro: Museu Nacional.

BUCKUP, PA., 1992. Redescription of Characidium fasciatum, type species of the Characidiinae (Teleostei, Characiformes). Copeia, vol. 1992, sup. supplement 4, p. 1066-1073. http://dx.doi. org/10.2307/1446639.

BUCKUP, PA., 1999. Sistemática e biogeografia de peixes de riachos. In CARAMASCHI, EP., MAZZONI, R. and PERESNETO, TR. (Ed.). Ecologia de peixes de riachos. Rio de Janeiro: Universidade Federal do Rio de Janeiro. p. 91-138. Série Oecologia Brasiliensis, vol. 6.

CALOR, AR., 2007. Trichoptera. In FROEHLICH, CG. (Org.). Guia on-line: identificação de larvas de insetos aquáticos do estado de São Paulo. Available from: <http://sites.ffclrp.usp.br/ aguadoce/index_trico $>$.

CARVALHO, AL., 1999. Insetos odonatas. In ISMAEL, D., VALENTI, WC., MATSUMURA-TUNDISI, T. and ROCHA, O. (Ed.). Biodiversidade do Estado de São Paulo, Brasil: invertebrados de água doce. São Paulo: FAPESP. vol. 4. p. 149-155.

CASTRO, RMC., 1999. Evolução da ictiofauna de riachos sulamericanos: padrões gerais e possíveis processos causais. In CARAMASCHI, EP., MAZZONI, R. and PERES-NETO, TR. (Ed.). Ecologia de peixes de riachos. Rio de Janeiro: Universidade Federal do Rio de Janeiro. p. 139-155. Série Oecologia Brasiliensis, vol. 6.

COELHO, PA. and RAMOS-PORTO, M., 1984. Camarões de água doce do Brasil: distribuição geográfica. Revista Brasileira de Zoologia, vol. 2, no. 6, p. 405-410. http://dx.doi.org/10.1590/ S0101-81751984000200014.

COSTA, JM., SOUZA, LO. and OLDRINI, BB., 2004. Chave para identificação das famílias e gêneros das larvas conhecidas de odonatas do Brasil: comentários e registros bibliográficos (Insecta, Odonata). Publicações Avulsas do Museu Nacional, vol. 99, p. 1-44.

CHAMON, CC., ARANDA, AT. and BUCKUP, PA., 2005. Pareiorhina brachyrhyncha (Loricariidae: Siluriformes): a new species of fish from the Paraíba do Sul slope of Serra da Mantiqueira, southeastern Brazil. Copeia, vol. 2005, sup. supplement 3, p. 550-558. http://dx.doi.org/10.1643/CI-04-276R

CHRISTOFOLETTI, A., 1980. Geomorfologia. 2nd ed. São Paulo: Edgard Blücher.

DA-SILVA, ER., SALLES, FF. and BAPTISTA, MS., 2002. As brânquias dos gêneros de Leptophlebiidae (Insecta: Ephemeroptera) ocorrentes no Estado do Rio de Janeiro. Biota Neotropica, vol. 2, no. 2. Available from: $<\mathrm{http} / /$ www.biotaneotropica.org.br/v2n2/ pt/abstract?short-communication+BN00902022002>.

DE GRAVE, S., CAI, Y. and ANKER, A., 2008. Global diversity of shrimps (Crustacea: Decapoda: Caridea) in freshwater. Hydrobiologia, vol. 595, no. 1, p. 287-293. http://dx.doi.org/10.1007/ s10750-007-9024-2.

DE MOOR, FC. and IVANOV, VD., 2008. Global diversity of caddisflies (Trichoptera: Insecta) in freshwater. Hydrobiologia, vol. 595, no. 1, p. 393-407. http://dx.doi.org/10.1007/s10750007-9113-2.
DUELLMAN, WE., 1999. Patterns of distribution of amphibians: a global perspective. Baltimore: Johns Hopkins University Press.

FERNÁNDEZ, HR. and DOMINGUEZ, E., 2001. Guía para la determinación de los artrópodos bentónicos sudamericanos. Tucumán: Universidad Nacional de Tucumán/Facultad de Ciencias Naturales/Instituto M. Lillo.

FLINT, OS., HOLZENTHAL, RW. and HARRIS, SC., 1999. Nomenclatural and systematic changes in the Neotropical caddisflies (Insecta: Trichoptera). Insecta Mundi, vol. 13, p. 73-84.

FLORENZANO, TG., 2008. Geomorfologia: conceitos e tecnologias atuais. São Paulo: Oficina de Textos. 318 p.

FOCHETTI, R. and TIERNO DE FIGUEROA, JM., 2008. Global diversity of stoneflies (Plecoptera; Insecta) in freshwater. Hydrobiologia, vol. 595, no. 1, p. 365-377. http://dx.doi.org/10.1007/ s10750-007-9031-3.

FORNERIS, L., 1999a. Platelmintos turbelários. In ISMAEL, D., VALENTI, WC., MATSUMURA-TUNDISI, T. and ROCHA, O. (Ed.). Biodiversidade do Estado de São Paulo, Brasil: invertebrados de água doce. São Paulo: FAPESP. vol. 4. p. 17-23.

FORNERIS, L., 1999b. Nemertinos. In ISMAEL, D., VALENTI, WC., MATSUMURA-TUNDISI, T. and ROCHA, O. (Ed.). Biodiversidade do Estado de São Paulo, Brasil: invertebrados de água doce. São Paulo: FAPESP. vol. 4. p. 25-28.

FORNERIS, L., 1999c. Nematomorfos gordióides. In ISMAEL, D., VALENTI, WC., MATSUMURA-TUNDISI, T. and ROCHA, O. (Ed.). Biodiversidade do Estado de São Paulo, Brasil: invertebrados de água doce. São Paulo: FAPESP. vol. 4. p. 35-38

FORNERIS, L., 1999d. Ácaros. In ISMAEL, D., VALENTI, WC., MATSUMURA-TUNDISI, T. and ROCHA, O. (Ed.). Biodiversidade do Estado de São Paulo, Brasil: invertebrados de água doce. São Paulo: FAPESP. vol. 4. p. 85-90.

FORNERIS, L., 1999e. Briozoários. In ISMAEL, D., VALENTI, WC., MATSUMURA-TUNDISI, T. and ROCHA, O. (Ed.). Biodiversidade do Estado de São Paulo, Brasil: invertebrados de água doce. São Paulo: FAPESP. vol. 4. p. 53-57.

FROEHLICH, CL., 1999a. Outros insetos. In ISMAEL, D., VALENTI, WC., MATSUMURA-TUNDISI, T. and ROCHA, O. (Ed.). Biodiversidade do Estado de São Paulo, Brasil: invertebrados de água doce. São Paulo: FAPESP. vol. 4. p. 161-168.

FROEHLICH, CL., 1999b. Insetos plecópteros. In ISMAEL, D., VALENTI, WC., MATSUMURA-TUNDISI, T. and ROCHA, O. (Ed.). Biodiversidade do Estado de São Paulo, Brasil: invertebrados de água doce. São Paulo: FAPESP. vol. 4. p. 156-160

GARUTTI, V. and BRITSKI, HA., 2000. Descrição de uma espécie nova de Astyanax (Teleostei: Characidae) da Bacia do Alto Rio Paraná e considerações sobre as demais espécies do gênero na Bacia. Comunicações do Museu de Ciências e Tecnologia PUCRS, Série Zoologia, vol. 13, p. 65-88.

GLASBY, CJ. and TIMM, T., 2008. Global diversity of polychaetes (Polychaeta; Annelida) in freshwater. Hydrobiologia, vol. 595, no. 1, p. 107-115. http://dx.doi.org/10.1007/s10750-007-9008-2.

HUBBARD, MD. and PESCADOR, ML., 1999. Insetos efemerópteros. In ISMAEL, D., VALENTI, WC., MATSUMURATUNDISI, T. and ROCHA, O. (Ed.). Biodiversidade do Estado de São Paulo, Brasil: invertebrados de água doce. São Paulo: FAPESP. vol. 4. p. 134-140

JÄCH, MA. and BALKE, M., 2008. Global diversity of water beetles (Coleoptera) in freshwater. Hydrobiologia, vol. 595, no. 1, p. 419-442. http://dx.doi.org/10.1007/s10750-007-9117-y. 
JANKOWSKI, T., COLLINS, AG. and CAMPBELL, R., 2008. Global diversity of inland water cnidarians. Hydrobiologia, vol. 595, no. 1, p. 35-40. http://dx.doi.org/10.1007/s10750-007-9001-9.

JESUS, N. and CAVALHEIRO, F., 2004. Aspectos antrópicos, legais e conservacionistas na Serra do Japi, SP. In SANTOS, JE., CAVALHEIRO, F., PIRES, JSR., OLIVEIRA, CH. and PIRES, AMZCR. (Ed.). Faces da polissemia da paisagem: ecologia, planejamento e percepção. São Carlos: Rima. vol. 2. p. 805-821

Jundiai, Prefeitura Municipal. Resolução $n^{\circ} 11$, de 8 de março de 1983. Diário Oficial do Estado, São Paulo. Available from: $<$ http://cidade.jundiai.sp.gov.br/pmjsite/biblio.nsf/V03.01/ smpm/\$file/127.pdf>.

Jundiai, Prefeitura Municipal, 1998. Decreto $n^{\circ} 43.284$, de 3 de julho de 1998. Diário Oficial do Estado, São Paulo, 4 jul. Available from: $<$ http://cidade.jundiai.sp.gov.br/pmjsite/biblio. $\mathrm{nsf} / \mathrm{V} 03.01 / \mathrm{smpm} / \$$ file/126.pdf $>$.

Jundiai, Prefeitura Municipal, 2004. Lei Complementar n ${ }^{\circ} 417$, de 29 de dezembro de 2004. Cria o sistema de proteção das áreas da Serra do Japi; e revoga dispositivos do Plano Diretor.Available from: $<$ http://cidade.jundiai.sp.gov.br/pmjsite/biblio.nsf/V03.01/ smpm/\$file/165.zip>.

LECCI, LS. and FROEHLICH, CG., 2007. Plecoptera. In FROEHLICH, CG. (Org.). Guia on-line: identificação de larvas de insetos aquáticos do estado de São Paulo. Available from: $<$ http://sites.ffclrp.usp.br/aguadoce/index $>$.

LÉVÊQUE, C., OBERDORFF, T., PAUGY, D., STIASSNY, MLJ. and TEDESCO, PA., 2008. Global Diversity of Fish (Pisces) in Freshwater. Hydrobiologia, vol. 595, no. 1, p. 545-567. http:// dx.doi.org/10.1007/s10750-007-9034-0.

LEWINSOHN, T. and PRADO, PI., 2002. Biodiversidade brasileira: síntese do estado atual do conhecimento. São Paulo: Contexto.

LOPRETTO, EC. and TELL, G., 1995. Ecosistemas de águas continentales: metodologia para su estudio. Argentina: Ediciones SUR.

LUCINDA, PHI., 2008. Systematics and biogeography of the genus Phalloceros Eigenmann, 1907 (Cyprinodontiformes: Poeciliidae: Poeciliinae), with the description of twenty-one new species. Neotropical Ichthyology, vol. 6, no. 2, p. 113-158. http:// dx.doi.org/10.1590/S1679-62252008000200001.

MAGALHÃES, C., 1999. Crustáceos Decápodos. In ISMAEL, D., VALENTI, WC., MATSUMURA-TUNDISI, T. and ROCHA, O. (Ed.). Biodiversidade do Estado de São Paulo, Brasil: invertebrados de água doce. São Paulo: FAPESP. vol. 4. p. 125-133.

MANZO, V. and ARCHANGELSKY, M., 2008. A key to known larvae of South American Elmidae (Coleoptera: Byrrhoidea), with a description of the mature larva of Macrelmis saltensis Manzo. International Journal of Limnology, vol. 44, no. 1, p. 63-74. http://dx.doi.org/10.1051/limn:2008023.

MANCONI, R. and PRONZATO, R., 2008. Global diversity of sponges (Porifera: Spongillina) in freshwater. Hydrobiologia, vol. 595, no. 1, p. 27-33. http://dx.doi.org/10.1007/s10750-007-9000-x.

MARIANO, R. and FROEHLICH, CG., 2007. Ephemeroptera. In FROEHLICH, CG. (Org.). Guia on-line: identificação de larvas de insetos aquáticos do estado de São Paulo. Available from: $<\mathrm{http}: / /$ sites.ffclrp.usp.br/aguadoce/index $>$.

MARTIN, P., MARTINEZ-ANSEMIL, E., PINDER, A., TIMM, T. and WETZEL, MJ., 2008. Global diversity of oligochaetous clitellates ("Oligochaeta"; Clitellata) in freshwater. Hydrobiologia, vol. 595, no. 1, p. 117-127. http://dx.doi.org/10.1007/s10750007-9009-1.
MASSARD, JA. and GEIMER, G., 2008. Global Diversity of Bryozoans (Bryozoa or Ectoprocta) in freshwater. Hydrobiologia, vol. 595, no. 1, p. 93-99. http://dx.doi.org/10.1007/s10750-0079007-3.

MCCAFFERTY, WP., 1998. Aquatic entomology: the fishermen's and ecologists' illustrated guide to insects and their relatives. Toronto: Jones and Bartlett Publishers.

MELO, GA., 2003. Manual de identificação dos Crustacea Decapoda de água doce do Brasil. São Paulo: Loyola.

MENEZES, NA., WEITZMAN, SH., OYAKAWA, OT., LIMA, FCT., CASTRO, RM. and WEITZMAN, MJ., 2007. Peixes de água doce da Mata Atlântica: lista preliminar das espécies e comentários sobre conservação de peixes de água doce Neotropicais. São Paulo: MZUSP.

MERRITT, RW. and CUMMINS, KW., 1996. An introduction to the aquatic insects of North America. Dubuque: Kemdall/Hunt.

MACHADO, ABM., DRUMMOND, GM., PAGLIA, AP., 2008. Livro vermelho da fauna brasileira ameaçada de extinção. Brasília: MMA; Belo Horizonte: Fundação Biodiversitas. 2 vol. 1420 p.

MORELLATO, LPC., 1992. História natural da Serra do Japi: ecologia e preservação de uma floresta no sudeste do Brasil. Campinas: Ed. Unicamp/FAPESP.

MUGNAI, R., NESSIMIAN, JL. and BAPTISTA, DF., 2010. Manual de identificação de macroinvertebrados aquáticos do estado do Rio de Janeiro. Rio de Janeiro: Technical Books.

NIESER, N. and MELO, AL., 1997. Os heterópteros aquáticos de Minas Gerais: guia introdutório com chave de identificação para as espécies de Nepomorpha e Gerromorpha. Belo Horizonte: Ed. UFMG.

OLIFIERS, MH., DORVILLÉ, LFM., NESSIMIAN, JL. and HAMADA, N., 2004. A key to Brazilian genera of Plecoptera (Insecta) based on nymphs. Zootaxa, vol. 651, p. 1-15.

OYAKAWA, OT., AKAMA, A., MAUTARI, KC. and NOLASCO, JC., 2006. Peixes de riachos da Mata Atlântica nas Unidades de Conservação do Vale do Ribeira de Iguape no Estado de São Paulo. São Paulo: Neotropica.

OYAKAWA, OT. and MENEZES, NA., 2010. Checklist dos peixes de água doce do Estado de São Paulo, Brasil. Biota Neotropica, vol. 11, no. 1a. Available from: <http://www.biotaneotropica.org. br/v11n1a/pt/abstract?inventory+bn0021101a2011>.

PAPROCKI, H., HOLZENTHAL, RW. and BLAHNIK, RJ., 2004. Checklist of the Trichoptera (Insecta) of Brazil. Biota Neotropica, vol. 4, no. 1. Available from: <http://www.biotaneotropica.org. br/v4n1/pt/abstract?inventory+BN01204012004>

PASSOS, MIS., NESSIMIAN, JL. and FERREIRA JUNIOR, N., 2007. Chaves para identificação dos gêneros de Elmidae (Coleoptera) ocorrentes no Estado do Rio de Janeiro, Brasil. Revista Brasileira de Entomologia, vol. 51, no. 1, p. 42-53. http:// dx.doi.org/10.1590/S0085-56262007000100008.

PINHO, LC., 2008. Diptera. In FROEHLICH, CG. (Org.). Guia on-line: identificação de larvas de insetos aquáticos do estado de São Paulo. Available from: <http://sites.ffclrp.usp.br/aguadoce/index $>$.

POMPEU, PS., REIS, LS., GANDINI, CV., SOUZA, RCR. and FAVERO, JM, 2009. The Ichthyofauna of upper rio Capivari: defining conservation strategies based on the composition and distribution of fish species. Neotropical Ichthyology, vol. 7, no. 4, p. 659-666. http://dx.doi.org/10.1590/S1679-62252009000400015.

POINAR JUNIOR, G., 2008. Global diversity of hairworms (Nematomorpha: Gordiaceae) in freshwater. Hydrobiologia, vol. 595, no. 1, p. 79-83. http://dx.doi.org/10.1007/s10750-007-9112-3. 
RADA, M., RUEDA-ALMONACID, JV., VELÁSQUEZ-ÁLVAREZ, AA. and SÁNCHEZ-PACHECO, SJ., 2007. Descripción de las larvas de dos Centrolénidos (Anura: Centrolenidae) del noroccidente de la Cordillera Oriental, Colombia. Papéis Avulsos de Zoologia, vol. 47, p. 259-272.

REIS, RE., KULANDER, SO. and FERRARIS, CJ., 2003. Check list of the freshwater fishes of South and Central America. Porto Alegre: EDIPUCRS.

RIBEIRO, RS., EGITO, GTBT. and HADDAD, CRB., 2005. Chave de identificação: anfíbios anuros da vertente de Jundiaí da Serra do Japi, Estado de São Paulo. Biota Neotropica, vol. 5, no. 2. Available from: <http://www.biotaneotropica.org.br/v5n2/ pt/abstract?identification-key+bn03005022005>.

RIGHI, G., 1999. Anelídeos oligoquetos. In ISMAEL, D., VALENTI, WC., MATSUMURA-TUNDISI, T. and ROCHA, O. (Ed.). Biodiversidade do Estado de São Paulo, Brasil: invertebrados de água doce. São Paulo: FAPESP. vol. 4. p. 81-84.

$<$ bok>RIO GRANDE DO SUL. Secretaria Estadual da Saúde. Centro Estadual de Vigilância em Saúde, 2006. Simulídeos: Programa Estadual do Rio Grande do Sul, Brasil: chave para identificação de pupas da família Simuliidae (Diptera, Namatocera) para apoio às equipes regionais e municipais na determinação das espécies. Porto Alegre: CEVS.</bok>

ROCHA, O., 2002. Perfil do conhecimento de biodiversidade em águas doces no Brasil. In LEWINSOHN, T. and PRADO, PI. (Ed.). Biodiversidade brasileira: síntese do estado atual do conhecimento. São Paulo: Contexto. p. 165-169.

RODRIGUEZ, RR. and SHEPHERD, GJ., 1992. Análise da variação estrutural e fisionômica da vegetação e características edáficas, num gradiente altitudinal na Serra do Japi. In MORELLATO, LPC. (Ed.). História natural da Serra do Japi: ecologia e preservação de uma floresta no sudeste do Brasil. São Paulo: Ed. Unicamp/ FAPESP. p. 64-81

ROLLA, APPR., 2008. A ictiofauna da Serra do Japi (SP): bases para conservação. São Paulo: Instituto de Pesca. 177 p. Dissertação de Mestrado em Aquicultura e Pesca.

ROLLA, APPR., ESTEVES, KE. and YOSHIDA, CE., 2012. Ecologia e conservação de peixes de riachos da Serra do Japi. In VASCONCELLOS-NETO, J., POLLI, PR. and PENTEADODIAS, AM. (Ed.). Novos olhares, novos saberes sobre a Serra do Japi: ecos de sua biodiversidade. Curitiba: CRV. In press.

RUPPERT, EE., FOX, RS. and BARNES, RD., 2005. Zoologia dos invertebrados. São Paulo: Roca.

SALLES, FF., LUGO-ORTIZ, CR., DA-SILVA, ER. and FRANCISCHETTI, CN., 2003. Novo gênero e espécie de Baetidae (Insecta: Ephemeroptera) do Brasil. Arquivos do Museu Nacional. Museu Nacional (Brazil), vol. 61, p. 23-30.

SANTORO, E. and MACHADO, DL., 1992. Elementos geológicos da Serra do Japi. In MORELLATO, LPC. (Ed.). História natural da Serra do Japi: ecologia e preservação de uma floresta no Sudeste do Brasil. São Paulo: Ed Unicamp/FAPESP. p. 24-29.

São Paulo, Assembleia Legislativa do Estado de São Paulo, 1995. Lei n 9.146 , de 9 de março de 1995. Cria mecanismos de compensação financeira para municípios nos casos que especifica e dá providências. Diário Oficial do Estado, São Paulo, 10 março. Available from: $<$ http://www.al.sp.gov.br/norma/?id=11618>.

Sociedade Brasileira de Herpetologia - SBH, 2010. Brazilian amphibians: list of species. Available from: $<$ http://www. sbherpetologia.org.br>.
SCHOCKAERT, ER., HOOGE, M., SLUYS, R., SCHILLING, S., TYLER, S. and ARTOIS, T., 2008. Global diversity of free living flatworms (Platyhelminthes, "Turbellaria") in freshwater. Hydrobiologia, vol. 595, no. 1, p. 41-48. http://dx.doi.org/10.1007/ s10750-007-9002-8.

SILVEIRA, FL. and SCHLENZ, E., 1999. Cnidários. In ISMAEL, D., VALENTI, WC., MATSUMURA-TUNDISI, T. and ROCHA, O. (Ed.). Biodiversidade do Estado de São Paulo, Brasil: invertebrados de água doce. São Paulo: FAPESP. vol. 4. p. 11-15.

SIMONE, LRL., 1999. Moluscos gastrópodos. In ISMAEL, D., VALENTI, WC., MATSUMURA-TUNDISI, T. and ROCHA, O. (Ed.). Biodiversidade do Estado de São Paulo, Brasil: invertebrados de água doce. São Paulo: FAPESP. vol. 4. p. 69-72.

STANFORD, JA., 1996. Landscapes and catchments basins. In HAUER, FR., and LAMBERT, GA. (Ed.). Methods in stream ecology. San Diego: Academic Press. p. 3-22.

STEINER, TM. and AMARAL, AC., 1999. Anelídeos poliquetos. In ISMAEL, D., VALENTI, WC., MATSUMURA-TUNDISI, T. and ROCHA, O. (Ed.). Biodiversidade do Estado de São Paulo, Brasil: invertebrados de água doce. São Paulo: FAPESP. vol. 4. p. 73-79.

STRIXINO, ST. and STRIXINO, G., 1999. Insetos Dípteros quironomídeos. In ISMAEL, D., VALENTI, WC., MATSUMURATUNDISI, T. and ROCHA, O. (Ed.). Biodiversidade do Estado de São Paulo, Brasil: invertebrados de água doce. São Paulo: FAPESP. vol. 4. p. 141-148.

STRONG, EE., GARGOMINY, O., PONDER, WF. and BOUCHET, P., 2008. Global diversity of gastropods (Gastropoda; Mollusca) in freshwater. Hydrobiologia, vol. 595, no. 1, p. 149-166. http:// dx.doi.org/10.1007/s10750-007-9012-6.

SUNDBERG, P. and GIBSON, R., 2008. Global diversity of nemerteans (Nemertea) in freshwater. Hydrobiologia, vol. 595, no. 1, p. 61-66. http://dx.doi.org/10.1007/s10750-007-9004-6.

VALENTE, OF. and GOMES, MA., 2005. Conservação de nascentes: hidrologia e manejo de bacias hidrográficas de cabeceiras. Viçosa: Aprenda Fácil.

VENCES, M. and KÖHLER, J., 2008. Global diversity of amphibians (Amphibia) in freshwater. Hydrobiologia, vol. 595, no. 1, p. 569-580. http://dx.doi.org/10.1007/s10750-007-9032-2.

VOLKNER-RIBEIRO, C., 1999. Esponjas. In ISMAEL, D., VALENTI, WC., MATSUMURA-TUNDISI, T. and ROCHA, O. (Ed.). Biodiversidade do Estado de São Paulo, Brasil: invertebrados de água doce. São Paulo: FAPESP. vol. 4. p. 1-9.

WAGNER, R., BARTÁK, M., BORKENT, A., COURTNEY, G., GODDEERIS, B., HAENNI, J-P., KNUTSON, L., PONT, A., ROTHERAY, GE., ROZKOŠNÝ, R., SINCLAIR, B., WOODLEY, N., ZATWARNICKI, T. and ZWICK, P., 2008. Global diversity of dipteran families (Insecta Diptera) in freshwater (excluding Simuliidae, Culicidae, Chironomidae, Tipulidae and Tabanidae). Hydrobiologia, vol. 595, no. 1, p. 489-519. http://dx.doi.org/10.1007/ s10750-007-9127-9.

YEO, DCJ., NG, PKL., CUMBERLIDGE, N., MAGALHÃES, C., DANIELS, SR. and CAMPOS, MR., 2008. Global diversity of crabs (Crustacea: Decapoda: Brachyura) in freshwater. Hydrobiologia, vol. 595, no. 1, p. 275-286. http://dx.doi.org/10.1007/ s10750-007-9023-3.

YOSHIDA, CE. and GONÇALVES, L., 2004. Identificação de problemas e ameaças da APA Jundiaí-Cabreúva (Serra do Japi) através da análise dos talões de atendimento da guarda municipal de Jundiaí/SP. Bioikos, vol. 18, p. 5-10. 